\title{
Agronomic, nutritional and nutraceutical aspects of durum wheat (Triticum durum Desf.) cultivars under low input agricultural management
}

\author{
Giovanni Dinelli," Ilaria Marotti, ${ }^{1}$ Raffaella Di Silvestro, ${ }^{1}$ Sara Bosi, ${ }^{1}$ Valeria Bregola, ${ }^{1}$ \\ Mattia Accorsi, ${ }^{1}$ Alessandro Di Loreto, ${ }^{1}$ Stefano Benedettelli, ${ }^{2}$ Lisetta Ghiselli, ${ }^{2}$ \\ Pietro Catizone ${ }^{1}$ \\ ${ }^{1}$ Department of Agricultural Sciences, University of Bologna; ${ }^{2}$ Department of Crop, Soil and \\ Environmental Science, University of Florence, Italy
}

\begin{abstract}
Among cereals, durum wheat has a central role in the Italian diet and economy, where there is a historical tradition of pasta making. In the present study, we evaluated the nutrient and nutraceutical properties of 2 old and 6 modern durum wheat varieties grown under low input agricultural management. Considering the lack of available data on the adaptability of existing durum wheat varieties to the low input and organic sectors, the research aimed at providing a complete description of the investigated genotypes, considering the agronomic performance as well as the nutrient and phytochemical composition. The experimental trials were carried out at the same location (Bologna, Northern Italy) for two consecutive growing seasons (2006/2007, 2007/2008). No clear distinction between old and modern varieties was observed in terms of grain yield (mean values ranging from 2.5 to 4.0 t/ha), highlighting that the divergence in productivity, normally found between dwarf and non-dwarf genotypes, is strongly reduced when they are cropped under low input management. All durum wheat varieties presented high protein levels and, in addition, provided remarkable amounts of phytochemicals such as dietary fibre, polyphenols, flavonoids and carotenoids. Some of the investigated genotypes, such as Senatore Cappelli, Solex, Svevo and Orobel, emerged with intriguing nutritional and phytochemical profiles, with
\end{abstract}

Correspondence: Giovanni Dinelli, Department of Agricultural Sciences, University of Bologna, via Fanin 44, 40127, Bologna, Italy.

E-mail: giovanni.dinelli@unibo.it

Key words: durum wheat, low input agriculture, dietary fibre, antioxidants.

Conference presentation: SIA Congress, Bari 2012.

Acknowledgements: the authors wish to acknowledge the Fondazione del Monte di Bologna e Ravenna, Italy, for their financial support for this research.

Received for publication: 31 January 2013.

Revision received: 15 April 2013.

Accepted for publication: 27 April 2013.

(C) Copyright G. Dinelli et al., 2013

Licensee PAGEPress, Italy

Italian Journal of Agronomy 2013; 8:e12

doi:10.4081/ija.2013.e12

This article is distributed under the terms of the Creative Commons Attribution Noncommercial License (by-nc 3.0) which permits any noncommercial use, distribution, and reproduction in any medium, provided the original author(s) and source are credited. the highest levels of dietary fibre and antioxidant compounds. The study provided the basis for further investigations into the adaptability of the durum wheat genotypes to low input management, for the selection of genotypes characterised by higher yield and valuable nutrient and nutraceutical quality.

\section{Introduction}

Italy is the first world producer of pasta and has the highest pro capita consumption rates (http://www.internationalpasta.org). Due to the long tradition of pasta making, intense efforts have been made in the past to select durum wheat (Triticum durum Desf.) genotypes with the best agronomic performance. An increase in productivity was achieved during the first decades of the $20^{\text {th }}$ century after the introduction of the Senatore Cappelli variety selected by Nazareno Strampelli from North African landraces (Scarascia Mugnozza, 2005). After the Green Revolution (in the 1970s), the dwarf genes were introduced in Italy through breeding between the International Maize and Wheat Improvement Center (CIMMYT) short straw lines and local durum wheat varieties. This led to new durum wheat cultivars with high yield and improved technological quality (De Vita et al., 2007a, 2007b). Selection procedures were carried out to obtain genotypes that perform well under intensive crop management, but their adaptability to organic and low-input farming was never considered. At the moment, organic agriculture lacks crop varieties that can respond to the specific demands of this sector (i.e. high nitrogen use efficiency, competitiveness against weeds, resistance to biotic and abiotic stresses) as recently reviewed by Lammerts van Bueren et al. (2011). It is likely that the crossbreeding between old durum wheat genotypes and dwarf selection lines allowed some traits typical of old varieties to be maintained, such as wide adaptability and rusticity (Scarascia Mugnozza, 2005). These characteristics could play a key role in the choice of cultivars suitable for low-input farming. Moreover, the breeding programmes always focussed on improving yield and technological properties (i.e. gluten quality) and did not give much consideration to the nutritional and nutraceutical importance of wheat consumption in the human diet (Peccetti and Annicchiarico, 1998; Motzo et al., 2004). Recently, Fardet (2010) provided a complete description of the bioactive compounds present in whole wheat grains (including dietary fibre, polyphenols and carotenoids) and Gil et al. (2011) reported on the numerous studies that have demonstrated a direct relationship between wholegrain consumption and prevention of chronic diseases (i.e. diabetes, colon cancer). In addition, there is an increasing interest among both consumers and industries in the identification of specialty products with particular health-promoting properties, especially in the organic and functional food sectors. In this context, considering the scarce availability of literature data concerning the nutritional and 
nutraceutical properties of Italian durum wheat varieties, this study aimed to provide a comparative evaluation of the agronomic performance and the nutrient and phytochemical composition of old and modern durum wheat genotypes grown under low-input agricultural management.

\section{Materials and methods}

\section{Grain samples and field experiments}

Grain samples included 8 Italian durum wheat varieties (Triticum turgidum ssp. durum), including two old (Senatore Cappelli, Urria) and 6 modern (Anco Marzio, Iride, Levante, Orobel, Solex, Svevo) genotypes. Year of release and description of the pedigree of the varieties investigated are given in Figure 1. Trials were carried out at the experimental farm of the University of Bologna, Cadriano ( $44^{\circ} 33^{\prime} \mathrm{N}, 11^{\circ} 21^{\prime}$ E, $32 \mathrm{~m}$ asl), Italy, during the growing seasons 2006/2007 and $2007 / 2008$. The soil at the experimental farm is classified as fine silty, mixed, mesic, Udic Ustochrepts and has a silty loam texture with 380 , 375 and $245 \mathrm{~g} \mathrm{~kg}^{-1}$ of sand, silt and clay respectively. The $\mathrm{pH}$ (1: 2.5 soil to water) is 7.9 and organic carbon is $8.5 \mathrm{~g} \mathrm{~kg}^{-1}$. The field experiments were carried out using a randomised block design with 3 replicates (plot dimension $6 \times 5 \mathrm{~m}$ ). Data on monthly mean, minimum and maximum temperature recorded during the two growing seasons are shown in Table 1. During the 2-year study period, the total rainfall differed mostly during springtime, with lower rainfall in May and more abundant values in June of 2006/2007, as compared to the same month of the second year. As regards the temperature recorded during the first year, in general, higher values were observed as compared to 2007/2008. In particular, the period from April to June (2006/2007), which corresponds to the heading, anthesis and maturity stages of the crop, was hotter than that of the second growing season. Each genotype was grown in plots $(6 \times 5 \mathrm{~m})$ according to a low nitrogen input agrotechnique (nitrogen fertilization with $10 \mathrm{~kg} \mathrm{~N} \mathrm{ha}^{-1}$ applied before sowing and $20 \mathrm{~kg} \mathrm{NO}_{3} \mathrm{ha}^{-1}$ applied at leaf sheath lengthening stage). Weeds were controlled by hand and no herbicide (or other pesticide) treatment was applied throughout the entire crop cycle. Whole-grain samples were ground to semolina in a stone mill, immediately cooled to $-20^{\circ} \mathrm{C}$, and stored at this temperature until analysis.

\section{Chemicals}

Folin-Ciocalteu reagent, gallic acid, catechin, $\beta$-carotene were purchased from Sigma-Aldrich (St. Louis, M0, USA). Lutein and zeaxanthin were obtained from Extrasynthèse (Genay, France). HPLC-grade methanol and acetonitrile were purchased from Carlo Erba (Milan, Italy). All other chemicals and solvent were of analytical grade.

\section{Yield and grain quality traits}

The recorded data included plant height $(\mathrm{cm})$, grain yield (t/ha), harvest index (HI) (ratio of grain yield to grain-plus-straw yield), 1000kernel weight $(\mathrm{g})$ and test weight $(\mathrm{kg} / \mathrm{hL})$. One thousand-kernel weight was obtained as the mean value of 3 replicates of 100 seeds from each plot. Test weight was calculated using a Shopper chondrometer equipped with a $1 \mathrm{~L}$ container and reported as $\mathrm{kg} / \mathrm{hL}$ without reference to the moisture content.

\section{Macronutrients}

Grain protein was measured using the Kjeldahl procedure (N 5.7) (American Association of Cereal Chemists, method 46-12) (AACC, 1995). The gluten content was determined using the method previously described by Kieffer et al. (2007). Lipid analysis was carried out according to the AOAC (1990) using chloroform-methanol $(2: 1 \mathrm{v} / \mathrm{v})$ to extract lipid compounds. Starch was enzymatically hydrolysed and

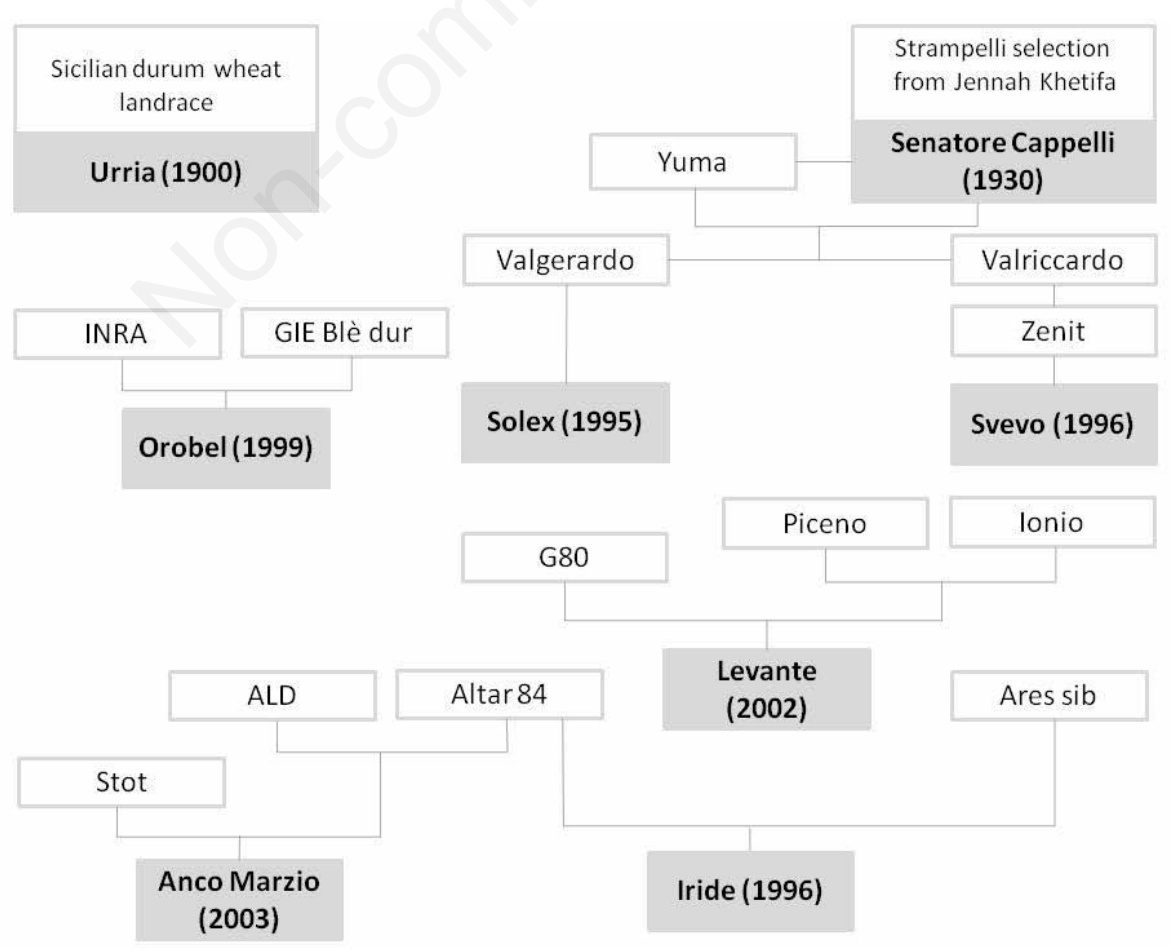

Figure 1. Genealogy and year of release of the durum wheat varieties investigated. 
measured using a Megazyme assay kit (Megazyme International Ireland Ltd, Wicklow, Ireland), as described by Di Silvestro et al. (2012).

\section{Dietary fibre and resistant starch analysis}

Total (TDF), insoluble (IDF) and soluble (SDF) dietary fibre content was determined using a Megazyme assay kit (Megazyme International Ireland Ltd., Wicklow, Ireland), following the enzymatic/gravimetric method described by Prosky et al. (1988). The procedure was based on the sequential enzymatic digestion of $1 \mathrm{~g}$ of flour, using heat-stable $\alpha$ amylase, protease and amyloglucosidase to remove protein and starch. The solution was then filtered to obtain the IDF residue and the filtrate was treated with $95 \%$ heated ethanol to precipitate the SDF. Both residues were dried and corrected for protein, ash and blank for final calculation of the IDF and SDF content. Resistant starch (RS) was determined with the Megazyme assay kit (Megazyme International Ireland Ltd.), as described by Marotti et al. (2012). After overnight $\alpha$ amylase and amyloglucosidase digestion, soluble starch was removed with $95 \%$ and $50 \%$ ethanol consecutive washes. The pellet was dissolved in potassium hydroxide solution, hydrolysed with amyloglucosidase and quantified using a glucose oxidase-peroxidase reagent.

\section{Phenolic compounds}

Free and bound phenolic compounds were extracted as previously described by Dinelli et al. (2011) with cold $80 \%$ ethanol followed by acid and alkaline hydrolyses. Extracts were analysed for the polyphenol quantification using the colorimetric procedure based on the FolinCiocalteu reagent, as described by Singleton et al. (1999). Appropriated dilutions of extracts were oxidised using Folin-Ciocalteu reagent, and the reaction was neutralised with sodium carbonate. After $120 \mathrm{~min}$, the absorbance of resulting blue colour was measured at $765 \mathrm{~nm}$ and converted using a gallic acid calibration curve. Furthermore, free and bound phenolic extracts were analysed for flavonoid content following the colorimetric method previously described by Dinelli et al. (2011), using catechin as a standard.

\section{Carotenoids}

Carotenoid content was determined according to Hentschel et al. (2002) and Topuz and Ozdemir (2003). Pigments were first extracted as described by Di Silvestro et al. (2012), then analysed using an RPHPLC (Beckman Coulter Inc., Miami, FL, USA) consisting of a Gold 126 multisolvent pump, photodiode array detector Beckman 168 and a
Spark Holland autosampler. For separation, a Waters RP C18 column $(4.6 \mathrm{~mm} \times 250 \mathrm{~nm}, 5 \mu \mathrm{m})$ was employed. The binary gradient (acetonewater, initially $75: 25$ ) was run at a flow rate of $1 \mathrm{~mL} / \mathrm{min}$ for $5 \mathrm{~min}$, then increased to $95: 5$ in $5 \mathrm{~min}$ and maintained at this level for $10 \mathrm{~min}$. Carotenoids were detected at $450 \mathrm{~nm}$ and identified by comparing retention time and spectra with those of lutein, $\beta$-carotene and zeaxanthin standards.

\section{Statistical analyses}

Data were subjected to analysis of variance (ANOVA, Tukey's honest significant difference multiple comparison) using Statistica 6.0 software (2001; StatSoft, Tulsa, OK, USA). The effects of genotype and growing season and their interaction were tested for significance by two-way ANOVA. Significance between means was determined by least significant difference values for $\mathrm{P}<0.05$. A linear discriminant analysis (LDA) was performed using Statistica 6.0 software (StatSoft). LDA was applied to the standardised data matrix of the nutrient and bioactive compounds obtained for the investigated durum wheat varieties from both cropping years. It allowed scoring of the cases as a function of the first two roots to provide a picture of the similarities among genotypes. LDA is a multivariate technique that increases the informative level on the variables that mainly influence similarities and differences between samples (Rodriguez-Delgado et al., 2002). LDA is also a statistical method used to find a linear combination of features (discriminant functions) that characterises or separates two or more classes of objects or events (McLachlan, 2004). The statistical significance of each discriminant function was evaluated on the basis of Wilks' Lambda factor, which ranges from 1.0 (no discriminatory power) to 0.0 (perfect discriminatory power).

\section{Results and discussion}

\section{Yield and commercial quality}

The main agronomic traits and commercial quality parameters of the investigated durum wheat varieties are reported in Table 2 . Grain yield significantly varied among genotypes and ranged from 2.5 to 4.0 t/ha. The highest yield value was obtained for the old variety Urria 12 (4.0 t/ha) along with other durum wheat genotypes, such as Iride (3.8 t/ha), Orobel (3.9 t/ha), Solex (3.9 t/ha) and Svevo (3.9 t/ha). The lowest pro-

Table 1. Monthly data recorded for rainfall $(\mathrm{mm})$, mean, minimum and maximum temperature $\left({ }^{\circ} \mathrm{C}\right)$ during the two cropping seasons $(2006 / 2007,2007 / 2008)$ at the experimental location (Cadriano, Bologna, Northern Italy).

\begin{tabular}{|c|c|c|c|c|c|c|c|c|}
\hline \multirow[b]{2}{*}{ Month } & \multicolumn{2}{|c|}{ Rainfall (mm) } & \multicolumn{2}{|c|}{ Mean temperature $\left({ }^{\circ} \mathrm{C}\right)$} & \multicolumn{2}{|c|}{ Minimum temperature $\left({ }^{\circ} \mathrm{C}\right)$} & \multicolumn{2}{|c|}{ Maximum temperature $\left({ }^{\circ} \mathrm{C}\right)$} \\
\hline & $2006 / 07$ & $2007 / 08$ & $2006 / 07$ & $2007 / 08$ & $2006 / 07$ & $2007 / 08$ & $2006 / 07$ & $2007 / 08$ \\
\hline October & 11.6 & 143.8 & 16.9 & 14.4 & 12.9 & 11.0 & 21.3 & 21.0 \\
\hline November & 41.8 & 17.0 & 10.7 & 8.7 & 7.4 & 5.8 & 14.3 & 12.2 \\
\hline December & 28.4 & 41.0 & 6.4 & 4.8 & 3.8 & 2.1 & 9.4 & 8.1 \\
\hline January & 10.6 & 48.6 & 6.7 & 6.2 & 4.0 & 3.8 & 10.2 & 9.1 \\
\hline February & 34.6 & 16.2 & 8.3 & 6.9 & 5.2 & 3.5 & 11.9 & 10.9 \\
\hline March & 100.4 & 54.2 & 10.9 & 10.6 & 6.8 & 6.6 & 15.1 & 14.8 \\
\hline April & 19.8 & 30.8 & 16.8 & 13.8 & 11.3 & 9.4 & 22.2 & 18.5 \\
\hline May & 41.8 & 133.2 & 20.5 & 18.4 & 15.5 & 13.5 & 25.8 & 23.1 \\
\hline June & 131.8 & 87.8 & 23.2 & 22.6 & 18.8 & 17.8 & 28.2 & 27.9 \\
\hline July & 1.2 & 10.4 & 27.0 & 26.4 & 21.0 & 20.3 & 32.9 & 31.0 \\
\hline
\end{tabular}


ductivity was obtained for the modern variety Anco Marzio (2.5 t/ha), while Levante and Senatore Cappelli showed intermediate values (3.3 tha). The observed grain yield was lower than values previously reported for modern and old durum wheat varieties grown under low and high levels of nitrogen inputs (Quaranta et al., 2010; De Vita et al., 2007b; Giunta et al., 2007). These studies described high variability comparing durum wheat varieties released before and after the Second World War, reporting a significant rise in productivity of the newest varieties due to increasing spike fertility and density (spikes per square metre). However, this result was not confirmed in our study as there was no difference between the two old genotypes investigated and the other durum wheat varieties, suggesting that without high nitrogen inputs old and modern cultivars are comparable in terms of grain yield. Further studies focussing on how old and modern cultivars differ for each yield component may go further to explain the comparison between grain yield formation processes. The environmental conditions significantly affected the observed grain yield. During the second crop cycle, an increase in productivity was recorded compared to the previous year (3.8 and 3.4 t/ha, respectively), probably due to quite lower mean temperature and more homogenous rainfall distribution during the grain filling period (May-July). Indeed, the air temperature during grain filling may affect translocation rates of carbon and nitrogen compounds, determining the yield and the final protein concentration of wheat kernel (Vaccari et al., 2007). The wheat varieties investigated evidently differed in plant height. During the 1970s, breeding programs introduced the dwarf habitus in the Italian varieties through the introgression of the short-straw genes (Rht) of Norin 10 (Triticum aestivum L.) (De Vita et al., 2007a, 2007b). In the present study, modern varieties showed plant height values ranging from $66.9 \mathrm{~cm}$ (Anco Marzio) to $80.0 \mathrm{~cm}$ (Svevo). In contrast, the old wheat genotypes presented significantly taller straw: $116.0 \mathrm{~cm}$ (Urria 12) and $121.2 \mathrm{~cm}$ (Senatore Cappelli) (Table 2). As expected, the highest plant height corresponded to the lowest HI values: 0.21 and 0.22 for Senatore Cappelli and Urria 12, respectively. All the modern varieties presented significantly higher HI values: within $0.24-0.37$. The increase in $\mathrm{HI}$ as a function of the year of cultivar release was described in detail in previous studies concerning both durum and common wheat genotypes (De Vita et al., 2007b; Giunta et al., 2007). Besides the dwarf habitus, the rise in HI values was associated with the highest number of kernels per square metre, while other parameters such as number of spikelets per spike and spike length, did not show a clear trend in relation to breeding improvements. The HI values observed in the present study

Table 2. Yield, harvest index, plant height, test weight and 1000-kernel weight of the durum wheat genotypes investigated.

\begin{tabular}{|c|c|c|c|c|c|}
\hline Variety & $\begin{array}{l}\text { Grain yield } \\
\text { (t/ha) }\end{array}$ & Harvest index & $\begin{array}{l}\text { Plant height } \\
\text { (cm) }\end{array}$ & $\begin{array}{l}\text { Test weight } \\
\text { (kg/hL) }\end{array}$ & $\begin{array}{l}\text { 1000-kernel } \\
\text { weight (g) }\end{array}$ \\
\hline Anco Marzio & $2.5^{\mathrm{c}}$ & $0.24^{\mathrm{d}}$ & $66.9 c$ & $64.0^{c}$ & $33.9 c$ \\
\hline Iride & $3.8^{\mathrm{a}}$ & $0.30^{\mathrm{b}}$ & $76.2^{\mathrm{bc}}$ & $73.6^{\mathrm{b}}$ & $35.0^{c}$ \\
\hline Levante & $3.3^{b}$ & $0.30^{\mathrm{b}}$ & $72.7^{\mathrm{bc}}$ & $75.0^{\mathrm{ab}}$ & $38.3^{\mathrm{b}}$ \\
\hline Orobel & $3.9^{\mathrm{a}}$ & $0.36^{a}$ & $70.9^{\mathrm{bc}}$ & $78.2^{\mathrm{a}}$ & $41.1^{\mathrm{a}}$ \\
\hline Senatore Cappelli & $3.3^{\mathrm{b}}$ & $0.21^{\mathrm{e}}$ & $121.2^{\mathrm{a}}$ & $78.3^{\mathrm{a}}$ & $41.9^{\mathrm{a}}$ \\
\hline Solex & $3.9^{\mathrm{a}}$ & $0.37^{a}$ & $70.0^{\mathrm{bc}}$ & $77.2^{\mathrm{ab}}$ & $39.1^{\mathrm{b}}$ \\
\hline Svevo & $3.9^{\mathrm{a}}$ & $0.27^{c}$ & $80.0^{\mathrm{b}}$ & $74.7^{\mathrm{ab}}$ & $33.9^{c}$ \\
\hline Urria 12 & $4.0^{\mathrm{a}}$ & $0.22^{\mathrm{de}}$ & $116.0^{a}$ & $78.4^{\mathrm{a}}$ & $41.2^{\mathrm{a}}$ \\
\hline $\begin{array}{l}\text { Year } \\
2006 / 2007 \\
2007 / 2008\end{array}$ & $\begin{array}{l}3.4^{\mathrm{b}} \\
3.7^{\mathrm{a}}\end{array}$ & $\begin{array}{l}0.28^{\mathrm{a}} \\
0.29^{\mathrm{a}}\end{array}$ & $\begin{array}{l}83.8^{\mathrm{a}} \\
84.6^{\mathrm{a}}\end{array}$ & $\begin{array}{l}75.3^{\mathrm{a}} \\
74.5^{\mathrm{a}}\end{array}$ & $\begin{array}{l}38.0^{\mathrm{a}} \\
38.0^{\mathrm{a}}\end{array}$ \\
\hline Interaction $\mathrm{Vx} Y$ & ns & ns & ns & ns & ns \\
\hline
\end{tabular}

a,b,c,d,e Means followed by different letters are statistically different at $\mathrm{P}<0.05$. ns, not significant.

Table 3. Nutrient and dietary fibre composition of the durum wheat varieties investigated expressed as $\mathrm{g}$ per $\mathrm{kg}$ of wholegrain semolina.

\begin{tabular}{|c|c|c|c|c|c|c|c|c|}
\hline Variety & $\begin{array}{c}\text { Protein } \\
\mathrm{g} / \mathrm{kg}\end{array}$ & $\begin{array}{c}\text { Gluten } \\
\mathrm{g} / \mathrm{kg}\end{array}$ & $\begin{array}{l}\text { Starch } \\
\mathrm{g} / \mathrm{kg}\end{array}$ & $\begin{array}{l}\text { Lipid } \\
\mathrm{g} / \mathrm{kg}\end{array}$ & $\begin{array}{l}\text { TDF } \\
\mathrm{g} / \mathrm{kg}\end{array}$ & $\begin{array}{l}\text { SDF } \\
\mathrm{g} / \mathrm{kg}\end{array}$ & $\begin{array}{c}\text { SDF/TDF } \\
\%\end{array}$ & $\begin{array}{l}\text { RS } \\
\mathrm{g} / \mathrm{kg}\end{array}$ \\
\hline Anco Marzio & $147.4^{\mathrm{ab}}$ & $84.8^{d}$ & $544.7^{\mathrm{ab}}$ & $29.2^{\mathrm{cd}}$ & $193.5^{\mathrm{bc}}$ & $25.8^{c}$ & $13.4^{\mathrm{cd}}$ & $3.8^{\mathrm{cd}}$ \\
\hline Iride & $156.7^{\mathrm{a}}$ & $101.6^{\mathrm{b}}$ & $514.0^{\mathrm{ab}}$ & $32.3^{\mathrm{ab}}$ & $204.9^{\mathrm{a}}$ & $21.8^{\mathrm{d}}$ & $10.8^{\mathrm{e}}$ & $4.5^{c}$ \\
\hline Levante & $147.3^{\mathrm{ab}}$ & $103.4^{\mathrm{b}}$ & $526.7^{\mathrm{ab}}$ & $30.4^{\mathrm{bc}}$ & $189.0^{c}$ & $26.9^{c}$ & $14.2^{\mathrm{c}}$ & $5.0^{\mathrm{bc}}$ \\
\hline Orobel & $137.8^{\mathrm{b}}$ & $88.2^{\mathrm{d}}$ & $568.6^{\mathrm{a}}$ & $22.4^{\mathrm{e}}$ & $181.8^{\mathrm{d}}$ & $24.6^{c}$ & $13.6^{\mathrm{cd}}$ & $3.0^{\mathrm{d}}$ \\
\hline Senatore Cappelli & $163.8^{\mathrm{a}}$ & $120.1^{\mathrm{a}}$ & $505.0^{\mathrm{b}}$ & $27.4^{\mathrm{d}}$ & $199.0^{\mathrm{ab}}$ & $24.2^{c}$ & $12.2^{\mathrm{de}}$ & $8.2^{\mathrm{a}}$ \\
\hline Solex & $149.2^{\mathrm{ab}}$ & $96.9^{c}$ & $528.0^{\mathrm{ab}}$ & $30.7^{\mathrm{bc}}$ & $202.3^{\mathrm{a}}$ & $32.9^{\mathrm{b}}$ & $16.3^{\mathrm{b}}$ & $3.7^{\mathrm{cd}}$ \\
\hline Svevo & $159.6^{\mathrm{a}}$ & $101.2^{\mathrm{b}}$ & $536.7^{\mathrm{ab}}$ & $33.7^{\mathrm{a}}$ & $173.4^{\mathrm{e}}$ & $37.4^{\mathrm{a}}$ & $21.5^{\mathrm{a}}$ & $6.0^{\mathrm{b}}$ \\
\hline Urria 12 & $157.9^{\mathrm{a}}$ & $103.1^{\mathrm{b}}$ & $506.9^{\mathrm{b}}$ & $29.1^{\mathrm{cd}}$ & $192.6^{\mathrm{bc}}$ & $21.4^{\mathrm{d}}$ & $11.1^{\mathrm{e}}$ & $6.1^{\mathrm{b}}$ \\
\hline Year & & & & & & & & \\
\hline $\begin{array}{l}2006 / 2007 \\
2007 / 2008\end{array}$ & $\begin{array}{l}143.5^{\mathrm{b}} \\
161.4^{\mathrm{a}}\end{array}$ & $\begin{array}{c}94.5^{\mathrm{b}} \\
105.3^{\mathrm{a}}\end{array}$ & $\begin{array}{l}540.3^{\mathrm{a}} \\
517.4^{\mathrm{b}}\end{array}$ & $\begin{array}{l}20.9^{\mathrm{b}} \\
38.2^{\mathrm{a}}\end{array}$ & $\begin{array}{l}188.7^{\mathrm{b}} \\
195.5^{\mathrm{a}}\end{array}$ & $\begin{array}{l}26.7^{\mathrm{a}} \\
27.0^{\mathrm{a}}\end{array}$ & $\begin{array}{l}14.3^{\mathrm{a}} \\
14.0^{\mathrm{a}}\end{array}$ & $\begin{array}{l}6.8^{\mathrm{a}} \\
3.3^{\mathrm{b}}\end{array}$ \\
\hline $\begin{array}{c}\text { Interaction } \\
\mathrm{VxY}\end{array}$ & $* *$ & $* * *$ & ns & ns & $* * *$ & $* * *$ & $* * *$ & ns \\
\hline
\end{tabular}

TDF, total dietary fibre; SDF, soluble dietary fibre; $\mathrm{RS}$, resistant starch; ns, not significant. a,b,c,delemeans followed by different letters are statistically different at $\mathrm{P}<0.05$. ${ }^{*} \mathrm{P}<0.05 ;{ }^{* *} \mathrm{P}<0.01 ;{ }^{* * *} \mathrm{P}<0.001$. 
were lower than those commonly obtained for durum wheat grown under conventional (high $\mathrm{N}$ input) farming, but aligned with values reported for low nitrogen input management (De Vita et al., 2007b; Giunta et al., 2007). All the investigated durum wheat varieties investigated presented test weight values lower than market requests ( $>80$ $\mathrm{kg} / \mathrm{hL}$ ) (De Vita et al., 2007a) (Table 2). The modern variety Anco Marzio showed the lowest test weight $(63.9 \mathrm{~kg} / \mathrm{hL})$. Orobel and the old genotypes Senatore Cappelli and Urria 12 presented test weights close to the commercially accepted threshold limit $(78.2-78.4 \mathrm{~kg} / \mathrm{hL})$, showing a possible higher adaptability to the low input growing conditions. These genotypes also presented the highest 1000-kernel weight, within 41.1-41.9 $\mathrm{g}$ (Table 2) and, therefore, showed the best grain commercial quality. The remaining durum wheat varieties had significantly lower 1000-kernel weight, with Anco Marzio, Iride and Svevo showing the lowest values $(33.9,35.0$ and $33.9 \mathrm{~g}$, respectively). The kernel weight obtained aligned with data previously reported for old and modern durum wheat varieties by De Vita et al. (2007b). The environmental conditions had no impact on commercial quality parameters (test weight, 1000-kernel weight) as no differences were observed when the two growing seasons were compared.

\section{Macronutrient profile}

The macronutrient composition of the old and modern durum wheat varieties is presented in Table 3 . The investigated durum wheat genotypes showed protein content ranging from 137.8 to $163.8 \mathrm{~g} / \mathrm{kg}$ (Table 3 ). The modern variety Orobel presented the lowest protein yield, while several genotypes, including the old (Senatore Cappelli, Urria 12) and modern (Iride, Svevo) ones, showed significantly higher protein content. All the varieties studied presented protein amounts that were higher than the minimum industry standard set at $125 \mathrm{~g} / \mathrm{kg}$ (De Vita et al., 2007a). The observed protein levels were in line with those previously reported for old and modern durum wheat varieties cropped under low N input management (Quaranta et al., 2010; De Vita et al., 2007b) and were also comparable with those obtained at higher nitrogen rates by Giuliani et al. (2011). The protein accumulation was shown to be highly dependent on genotype, soil fertility (available N) and environmental conditions (temperature, water) (Giuliani et al., 2011; Dupont et al., 2006). In our study, the growing season was observed to have a big effect on protein content, with a significant increase from 143.5 to $161.4 \mathrm{~g} / \mathrm{kg}$ during the second year compared to the previous one. The significant interaction between variety and year (Figure 2) clearly shows that the rise in protein levels was mainly the result of the highest accumulation rates in the grains of Iride, Solex, Svevo and Senatore Cappelli, while the remaining genotypes presented stable protein amounts between years. This finding suggests that, under low input conditions, the protein yield is mainly determined by the nutrient use efficiency of each wheat genotype. Besides the protein quantity, durum wheat genotypes may vary greatly in protein quality and composition as a result of differences in genetic and agricultural management. The technological properties of the modern durum wheat varieties were improved by selecting genotypes with high gluten content and quality (i.e. strength, tenacity, extensibility). However, the technological quality is only guaranteed when these genotypes are cropped under high nitrogen supply (conventional agriculture)
A)

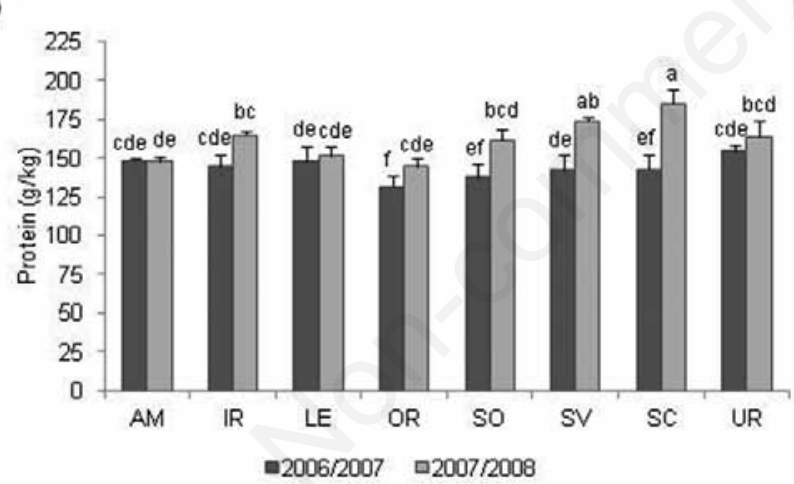

D)

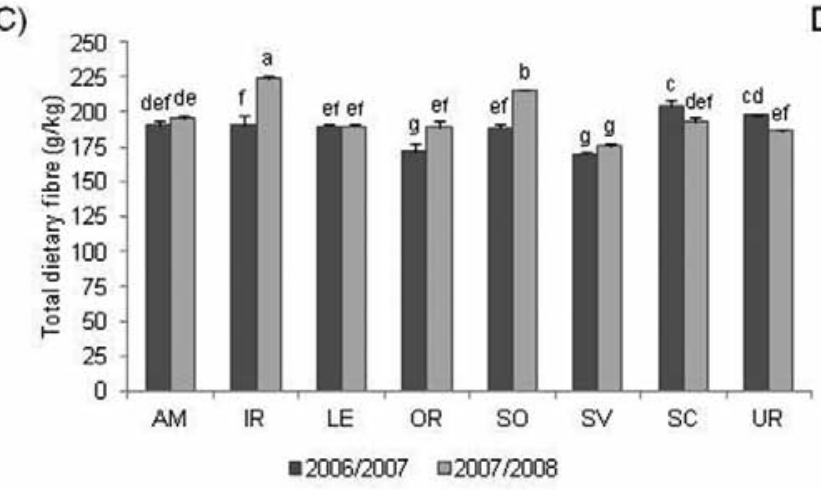

B)

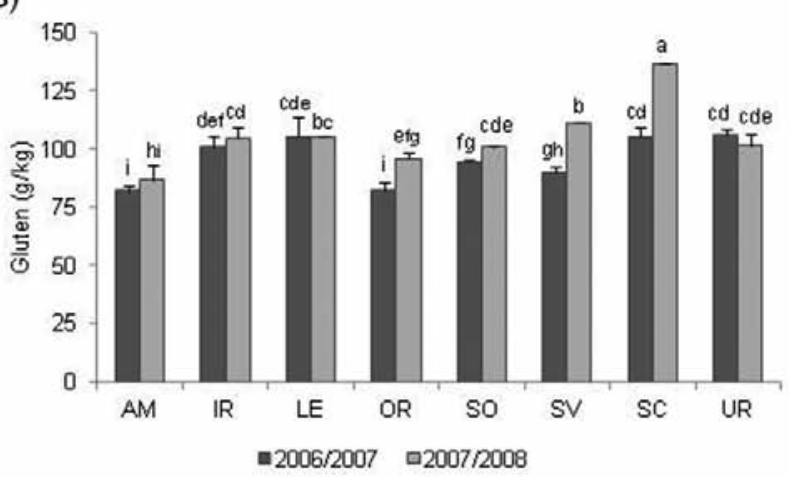

)

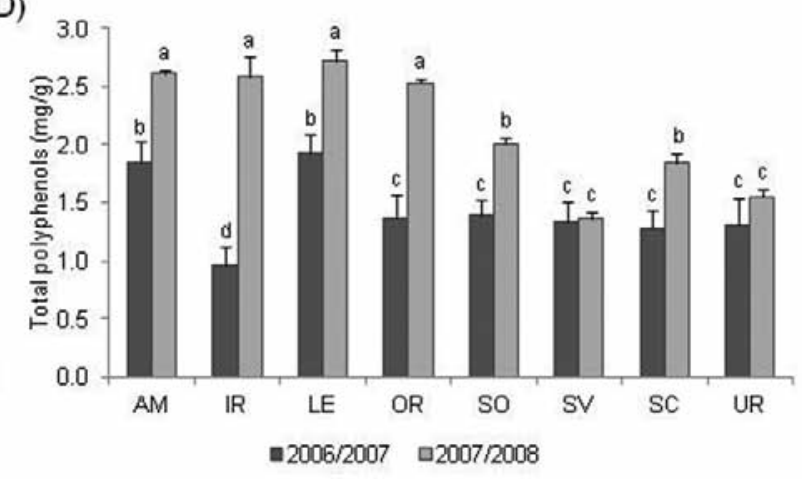

Figure 2. Significant interactions observed between variety and year for (A) protein, (B) gluten, (C) total dietary fibre and (D) total polyphenol content ( \pm standard error). a,b,c,d,e,f,g,h,i, means followed by different letters are statistically different at $\mathrm{P}<0.05 ; \mathrm{AM}$, Anco Marzio; IR, Iride; LE, Levante; OR, Orobel; SC, Senatore Cappelli; SO, Solex; SV, Svevo; UR, Urria. 
(Giuliani et al., 2011). In our study, the highest gluten content was obtained for the old variety Senatore Cappelli $(120.1 \mathrm{~g} / \mathrm{kg})$, while some modern cultivars, such as Anco Marzio, Orobel and Solex, presented very low gluten levels: within $84.8-96.9 \mathrm{~g} / \mathrm{kg}$ (Table 3 ). The effect of the cropping year was also observed for the gluten content that significantly increased during 2007/2008, as Orobel, Svevo and Senatore Cappelli responded to favourable growing conditions with a higher accumulation of gliadin and glutenin proteins (Figure 2). The durum wheat varieties investigated presented a total starch amount ranging from 505.0 to $568.6 \mathrm{~g} / \mathrm{kg}$ (Table 3). As expected, an inverse relationship between protein and starch levels was observed, with Senatore Cappelli and Urria 12 showing the lowest starch accumulation $(505.0$ and $506.9 \mathrm{~g} / \mathrm{kg}$, respectively), while Orobel had the highest $(568.6 \mathrm{~g} / \mathrm{kg})$. The effect of environmental growing conditions on macronutrient accumulation was also observed when comparing the mean value of starch content for each year; this showed a decrease from 540.3 to 517.4 during 2007/2008. Starch levels agreed with those previously reported for wholegrain semolina (Labuschagne et al., 2009). High variability was observed among durum wheat varieties for lipid content (Table 3). The highest values were obtained for the modern cultivars Svevo (33.7 $\mathrm{g} / \mathrm{kg}$ ) and Iride $(32.4 \mathrm{~g} / \mathrm{kg})$, while Orobel had the lowest fat content $(22.4 \mathrm{~g} / \mathrm{kg})$. High levels of fats in wholegrain semolina can affect the shelf life of the final product causing rancidity and loss of yellow pigments (due to lipoxygenase, peroxidise and polyphenol oxidase activities) (Aalami et al., 2007), but lipids are also interesting from a nutraceutical point of view, as they include compounds belonging to the vitamin E complex (tocopherols, tocotrienols) that exert strong antioxidant activity (Borrelli et al., 2008; Shewry et al., 2010).

\section{Dietary fibre content}

Dietary fibre is the predominant bioactive component of wholewheat grain. Due to its multiple health benefits, which include prevention of colon cancer, prebiotic activity and modulation of blood glucose and insulin levels, dietary fibre makes a big contribution to the nutraceutical value of wheat-based products (Charalampopoulos et al., 2010). As regards dietary fibre content, there was a big difference between the wheat varieties investigated in terms of both soluble and insoluble fibre components (Table 3). TDF ranged from $173.4 \mathrm{~g} / \mathrm{kg}$
(Svevo) to $204.9 \mathrm{~g} / \mathrm{kg}$ (Iride), while SDF was between $21.4 \mathrm{~g} / \mathrm{kg}$ (Urria 12 ) and $37.4 \mathrm{~g} / \mathrm{kg}$ (Svevo). Considering the SDF/TDF ratio, the modern varieties Solex and Svevo emerged with the highest proportion of SDF ( $16 \%$ and $22 \%$ of the total amount, respectively). On the contrary, Iride, Senatore Cappelli and Urria 12 had the lowest values of SDF percentage $(10 \%, 11 \%$ and $12 \%$, respectively), showing a preponderance of insoluble fibre components. TDF content was higher than that previously reported by Gebruers et al. (2008) for wholemeal durum wheat. However, the difference may be explained by the strong influence that genotype and environmental conditions have on the accumulation of fibre components in wheat grain (Gebruers et al., 2010; Shewry et al., 2010). The significant interaction between variety and year (Figure 2) showed that the durum wheat genotypes with the highest TDF amount (Iride, Solex) were those most influenced by the environmental conditions, while the other varieties had stable fibre content over the growing seasons. These results again underline the important effect of climate and growing factors and the need for in-depth investigation of the genotype per environment effects on the accumulation of fibres in the grain. The present research also evaluated RS content, a fraction of the starch that cannot be digested by human gastrointestinal enzymes and is fermented by the colon microflora, exerting high prebiotic activity (Sajilata et al., 2006; Fuentes-Zaragoza et al., 2010). For its physiological properties, RS is commonly referred to as a dietary fibre component. Very different levels of RS were detected in the investigated durum wheat genotypes (Table 3 ). The old variety Senatore Cappelli was the richest in RS ( $8.2 \mathrm{~g} / \mathrm{kg}$ ) whereas the lowest value was obtained for Orobel $(3.0 \mathrm{~g} / \mathrm{kg})$. As previously observed for total dietary fibre, the growing season was seen to have a big effect on resistant starch content. In contrast to protein, lipid and TDF that increased during 2007/2008, all the durum wheat varieties presented a large reduction in RS content in the second year (mean value 6.8 and 3.3 for $2006 / 2007$ and 2007/2008, respectively). This confirmed the considerable impact that environmental factors may have on starch composition (i.e. amylose/amylopectin ratio) in the wheat grain (Labuschagne et al., 2009; Flagella, 2006). Available literature data generally agree with RS values obtained in the second year rather than in the previous year (Ragaee et al., 2006; Marotti et al., 2012).

Table 4. Polyphenol, flavonoid and carotenoid content of the durum wheat varieties investigated expressed as mg (polyphenols, flavonoids) and $\mu \mathrm{g}$ (carotenoids) per $\mathrm{g}$ of wholegrain semolina.

\begin{tabular}{|c|c|c|c|c|c|c|}
\hline Variety & $\begin{array}{l}\text { Free polyphenols } \\
\mathrm{mg} / \mathrm{g}\end{array}$ & $\begin{array}{l}\text { Total polyphenols } \\
\text { mg/g }\end{array}$ & $\begin{array}{l}\text { Free flavonoids } \\
\mathrm{mg} / \mathrm{g}\end{array}$ & $\begin{array}{l}\text { Total flavonoids } \\
\text { mg/g }\end{array}$ & $\begin{array}{l}\text { Lutein } \\
\mu \mathrm{g} / \mathrm{g}\end{array}$ & $\begin{array}{l}\text { Total carotenoid } \\
\mu \mathrm{g} / \mathrm{g}\end{array}$ \\
\hline Anco Marzio & $0.62^{\mathrm{b}}$ & $2.28^{\mathrm{a}}$ & $0.18^{\mathrm{ab}}$ & $0.41^{\mathrm{a}}$ & $1.61^{\mathrm{e}}$ & $3.35^{\mathrm{d}}$ \\
\hline Iride & $0.46^{\mathrm{c}}$ & $1.81^{\mathrm{c}}$ & $0.17^{\mathrm{bcd}}$ & $0.46^{\mathrm{a}}$ & $1.63^{\mathrm{e}}$ & $3.34^{\mathrm{d}}$ \\
\hline Levante & $0.60^{\mathrm{b}}$ & $2.36^{\mathrm{a}}$ & $0.19^{a}$ & $0.64^{\mathrm{a}}$ & $2.55^{\mathrm{c}}$ & $5.41^{\mathrm{b}}$ \\
\hline Orobel & $0.72^{\mathrm{a}}$ & $2.00^{\mathrm{b}}$ & $0.17 b^{c d}$ & $0.47^{\mathrm{a}}$ & $2.82^{\mathrm{b}}$ & $5.86^{\mathrm{a}}$ \\
\hline Senatore Cappelli & $0.39^{\mathrm{d}}$ & $1.60^{\mathrm{de}}$ & $0.17 \mathrm{~b}^{c d}$ & $0.47^{\mathrm{a}}$ & $1.71^{\mathrm{e}}$ & $3.40^{\mathrm{d}}$ \\
\hline Solex & $0.47^{c}$ & $1.74^{\text {cd }}$ & $0.15^{\mathrm{d}}$ & $0.46^{\mathrm{a}}$ & $1.50^{\mathrm{e}}$ & $3.28^{\mathrm{d}}$ \\
\hline Svevo & $0.46^{\mathrm{c}}$ & $1.39^{f}$ & $0.16^{\mathrm{cd}}$ & $0.45^{\mathrm{a}}$ & $3.23^{\mathrm{a}}$ & $6.09^{\mathrm{a}}$ \\
\hline Urria 12 & $0.33^{\mathrm{e}}$ & $1.49^{\text {ef }}$ & $0.18^{a b c}$ & $0.43^{\mathrm{a}}$ & $2.19^{\mathrm{d}}$ & $3.98^{\mathrm{c}}$ \\
\hline \multicolumn{7}{|l|}{ Year } \\
\hline $2006 / 2007$ & $0.71^{\mathrm{a}}$ & $1.51^{\mathrm{b}}$ & $0.15^{b}$ & $0.42^{b}$ & $2.15^{\mathrm{a}}$ & $4.36^{\mathrm{a}}$ \\
\hline $2007 / 2008$ & $0.30^{\mathrm{b}}$ & $2.15^{\mathrm{a}}$ & $0.18^{a}$ & $0.52^{\mathrm{a}}$ & $2.16^{\mathrm{a}}$ & $4.32^{\mathrm{a}}$ \\
\hline \multicolumn{7}{|l|}{ Interaction } \\
\hline VxY & $* * *$ & $* * *$ & $* *$ & ns & ns & ns \\
\hline
\end{tabular}

a,b,c,d,e,fMeans followed by different letters are statistically different at $\mathrm{P}<0.05 . * * \mathrm{P}<0.01 ; * * \mathrm{P}<0.001$. ns, not significant. 


\section{Phenolic compound content}

Polyphenols are the most representative antioxidant compounds of the wheat grain. They are mainly made up of phenolic acids and flavonoids (Dinelli et al., 2009). In wheat kernel, polyphenols can be found in the free soluble and the bound insoluble forms, both possessing strong antiradicalic power as well as anticancer and anti-inflammatory properties (Thompson, 1994; Jacobs et al., 1998). The phenolic composition of the investigated durum wheat varieties is presented in Table 4. Regarding total polyphenol content, statistically significant differences were observed among genotypes. Anco Marzio and Levante varieties had the highest amounts (2.28 and $2.36 \mathrm{mg} / \mathrm{g}$, respectively), Svevo showed the lowest content $(1.39 \mathrm{mg} / \mathrm{g})$, while the remaining durum wheat genotypes presented intermediate values. High variability was also observed in the free soluble fraction of polyphenols: range $0.33 \mathrm{mg} / \mathrm{g}$ (Urria 12) to $0.72 \mathrm{mg} / \mathrm{g}$ (Orobel). The biosynthesis and accumulation of phenolic compounds during kernel development is known to be highly dependent on the wheat variety and environmental conditions (abiotic and biotic stresses) (Stracke et al., 2009; Bellato et al., 2013). The impact of environmental effects was seen in a comparison of the mean values obtained for each growing season (1.52 and 2.15 $\mathrm{mg} / \mathrm{g}$ for the first and the second year, respectively). The variety per year significant interaction (Figure 2) confirmed that all the durum wheat genotypes investigated had increased phenolic amounts during the second growing season, except for Svevo and Urria 12 that did not vary between years. All durum wheat varieties had comparable total flavonoid content $(0.41-0.64 \mathrm{mg} / \mathrm{g}$ ) (Table 4$)$, but varied in the soluble/insoluble compound ratio, with Levante showing the highest $(0.64 \mathrm{mg} / \mathrm{g})$ and Solex the lowest $(0.15 \mathrm{mg} / \mathrm{g})$ free flavonoid amount. As observed for polyphenols, the effect of the cropping year led to a significant increase in the flavonoid content in all the durum wheat genotypes investigated (mean values 0.43 and 0.52 for 2006/2007 and 2007/2008, respectively). Most literature data report on the phenolic content exclusively in terms of free soluble fraction without considering the insoluble fraction that accounts for $50-75 \%$ of the total amount (Dinelli et al., 2009). The free phenolic contents obtained in the present study were higher than those previously reported for soluble compounds (Bellato et al., 2013; Ciccoritti et al., 2013), but were in line with those reported by Fares et al. (2010) that also took into consideration the insoluble phenolic fraction.

\section{Carotenoid content}

Carotenoids are pigments responsible for the bright yellow colour of semolina and pasta and, therefore, determine one of the main factors affecting durum wheat quality and consumer choice. From a nutraceutical point of view, these pigments are particularly interesting as they act as powerful antioxidant agents and can lower the incidence of agerelated macular degeneration of the human eye (Beatty et al., 2000; Bernstein et al., 2002). In durum wheat, carotenoid content has been reported to be a highly heritable trait (Borrelli et al., 2008). This is in agreement with the lack of variability observed in our study between growing seasons (Table 4). However, statistically significant differences were observed among genotypes for total carotenoid and lutein (which is the most representative pigment in durum wheat) content. The modern varieties Orobel and Svevo had the highest carotenoid levels (5.87 and $6.09 \mu \mathrm{g} / \mathrm{g}$, respectively). This is not surprising given the breeding improvements that selected durum wheat genotypes for higher yellow index values (Flagella, 2006). The lowest pigment contents (3.28-3.40 $\mu \mathrm{g} / \mathrm{g})$ were obtained for Anco Marzio, Iride, Senatore Cappelli and Solex varieties. Lutein accounted for approximately half of the total carotenoid amount and ranged from $1.50 \mu \mathrm{g} / \mathrm{g}$ (Solex) to $3.23 \mu \mathrm{g} / \mathrm{g}$ (Svevo) (Table 4). The observed pigment contents were in general agreement with those previously reported for old and modern

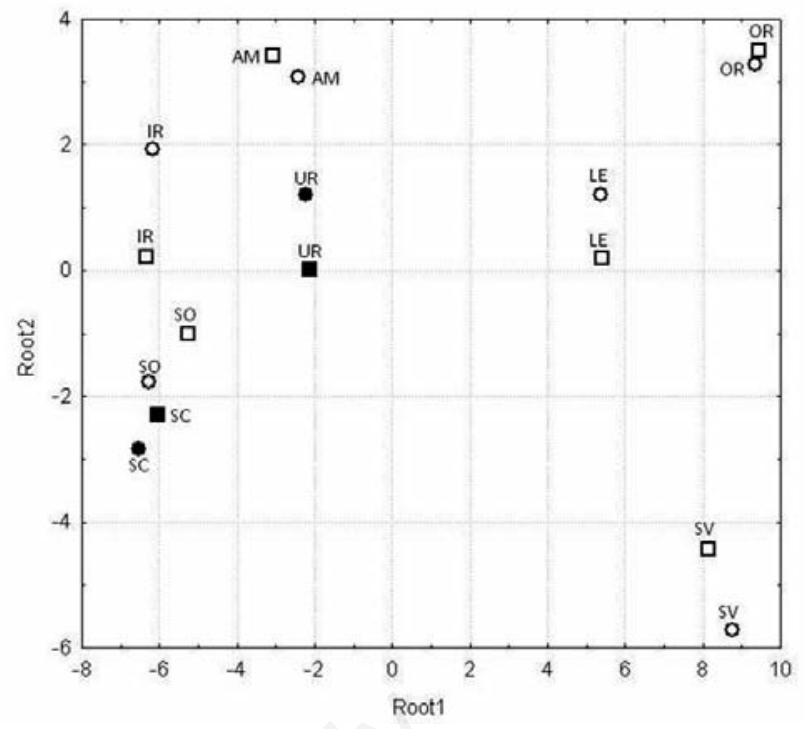

Figure 3. Scatterplot of the 6 modern (empty symbols) and 2 ancient (solid symbols) durum wheat varieties from both growing seasons according to the nutrient and phytochemical content defined by the first two canonical functions (Root 1 and Root 2, representing $71 \%$ and $13 \%$, respectively, of cumulated variability). Circle and square symbols refer to the first $(2006 / 2007)$ and second (2007/2008) growing season, respectively. AM, Anco Marzio; IR, Iride; LE, Levante; OR, Orobel; SC, Senatore Cappelli; SO, Solex; SV, Svevo; UR, Urria.

durum wheat varieties (Hung et al., 2011; Digesù et al., 2009; Panfili et al., 2004).

\section{Linear discriminant analysis}

LDA has been used to explain the observed variability in nutrient and phytochemical content of the wheat genotypes investigated harvested in two successive growing seasons (2006/2007, 2007/2008) Figure 3 shows the scatterplot of the wheat samples on the space defined by the first two canonical functions.

The Wilks' lambda value was 0.0000218 (significant at $\mathrm{P}<0.000001$ ), indicating the high discriminatory power of the applied model to classify wheat genotypes based on nutrient and phytochemical composition. The score of the cases in the plot did not show a clear differentiation between the two growing seasons or between old and modern durum wheat genotypes. For each genotype, the close position between samples grown in the first (2006/2007) and second (2007/2008) cropping year indicated that this environmental parameter had almost no influence on the investigated nutritional and phytochemical variables. In addition, the two old varieties (Senatore Cappelli, Urria) are clustered together with the modern varieties Iride, Anco Marzio, Solex. The remaining modern varieties (Orobel, Levante, Svevo) are clustered in a clearly separate group. As shown by the values of canonical functions standardised within variances, the described clusterisation of the cases along the first canonical function (Root 1) resulted strongly influenced by the content of lipids, total dietary fibres, free polyphenols, lutein and total carotenoids (first canonical discriminant function equal to -2.01 , $-0.75,1.02,0.68$ and 0.69 , respectively). For example, a gradient goes from the negative to the positive part of Root 1 that can be associated with increased content of free polyphenols, lutein and carotenoids. In complete contrast, the total dietary fibre content increases from the 
positive to the negative part of Root 1, as shown by the score of Iride, Solex and Senatore Cappelli varieties which had the highest TDF values. The clusterisation of the cases along second canonical function (Root 2) resulted strongly influenced by the gluten, soluble dietary fibre, resistant starch and free flavonoid content (second canonical discriminant function equal to $-0.97,-0.77,-1.15$ and 0.93 , respectively). The free flavonoid content increases from the negative to the positive arm of Root 2, determining the position of the Anco Marzio, Levante and Urria 12 varieties that showed the highest values, while gluten, resistant starch and soluble dietary fibre content has an opposite trend. According to the results obtained, the cropping year did not have a strong effect on kernel composition of primary and secondary metabolites. The particular phytochemical content of wheat grains mainly reflected their genealogy (Figure 1). Urria and Senatore Cappelli were originally selected from North African landraces, and Senatore Cappelli was in the breeding line of Solex. Anco Marzio and Iride shared a common parental line, while Orobel, Svevo and Levante were selected from crosses with durum semi-dwarf lines, originally obtained from North America.

\section{Conclusions}

The study highlighted that there was no great difference in agronomic performance between old and modern durum wheat varieties grown under low input agricultural management. While common wheat modern varieties were obtained directly from selected CYMMIT lines and are definitely distinct from the oldest genotypes, the dwarf durum wheat genotypes were selected by breeding the local Italian durum varieties (such as Senatore Cappelli, Urria 12 and others) with dwarf and semi-dwarf lines. Consequently, the genome of the modern durum wheat cultivars may include some traits of the ancient genotypes allowing the persistence of useful features for low-input management, such as wide adaptability and rusticity. Moreover, some of the genotypes investigated, such as Senatore Cappelli, Solex, Svevo and Orobel, presented intriguing nutritional and phytochemical profiles, with high levels of dietary fibre and antioxidant compounds. The study provided the basis for further investigation into the adaptability of the durum wheat genotypes to low input management, and for the selection of genotypes characterised by high yield and valuable nutrient and nutraceutical quality.

\section{References}

AACC, 1995. Approved method of American Association of Cereal Chemists. 9th ed. St. Paul, MN, USA.

Aalami M, Leelavathi K, Rao UJSP, 2007. Spaghetti making potential of Indian durum wheat varieties in relation to their protein, yellow pigment and enzyme content. Food Chem. 100:1243-8.

AOAC, 1990. Approved method of Association of Official Analytical Chemists. 5th ed. Arlington, VA, USA.

Beatty S, Koh H, Phil M, Henson D, Boulton M, 2000. The role of oxidative stress in the pathogenesis of age-related macular degeneration. Surv. Ophthalmol. 45:115-34.

Bellato S, Ciccoritti R, Del Frate V, Sgrulletta D, Carbone K, 2013. Influence of genotype and environment on the content of 5-n alkylresorcinols, total phenols and on the antiradical activity of whole durum wheat grains. J. Cereal Sci. 57:162-9.

Bernstein PS, Zhao DY, Wintch SW, Ermakov IV, McClane RW, Gellermann W, 2002. Resonance Raman measurement of macular carotenoids in normal subjects and in age-related macular degeneration patients. Ophthalmology 109:1780-87.

Borrelli GM, De Leonardis AM, Platani C, Troccoli A, 2008. Distribution along durum wheat kernel of the components involved in semolina colour. J. Cereal Sci. 48:494-502.

Charalampopoulos D, Severino S. Pandiella, Webb C, 2010. Uses of whole cereals and cereal components for the development of functional foods. In: M.L. Passos, C.P. Ribeiro (ed.) Innovations in food engineering: new techniques and products. CRC Press, Taylor \& Francis Group, Boca Raton, FL, USA, pp 635-653.

Ciccoritti R, Carbone K, Bellato S, Pogna N, Sgrulletta D, 2013. Content and relative composition of some phytochemicals in diploid, tetraploid and hexaploid Triticum species with potential nutraceutical properties. J. Cereal Sci. 57:200-6.

De Vita P, Di Paolo E, Fecondo G, Di Fonzo N, Pisante M, 2007a. Notillage and conventional tillage effects on durum wheat yield, grain quality and soil moisture content in southern Italy. Soil Till. Res. 92:69-78.

De Vita P, Li Destri Nicosia 0, Nigro F, Platani C, Riefolo C, Di Fonzo N, Cattivelli L, 2007b. Breeding progress in morpho-physiological, agronomical and qualitative traits of durum wheat cultivars released in Italy during the 20th century. Eur. J. Agron. 26:39-53.

Digesù AM, Platani C, Cattivelli L, Mangini G, Blanco A, 2009. Genetic variability in yellow pigment components in cultivated and wild tetraploid wheats. J. Cereal Sci. 50:210-8.

Dinelli G, Segura-Carretero A, Di Silvestro R, Marotti I, Arráez-Román D, Benedettelli S, Ghiselli L, Fernandez-Gutierrez A, 2011. Profiles of phenolic compounds in modern and old common wheat varieties determined by liquid chromatography coupled with time-of-flight mass spectrometry. J. Chromatogr. A. 1218:7670-81.

Dinelli G, Segura-Carretero A, Di Silvestro R, Marotti I, Fu S, Benedettelli S, Ghiselli L, 2009. Determination of phenolic compounds in modern and old varieties of durum wheat using liquid chromatography coupled with time-of-flight mass spectrometry. J. Chromatogr. 1216:7229-40.

Di Silvestro R, Marotti I, Bosi S, Bregola V, Segura-Carretero A, Sedej I, Mandic A, Sakac M, Benedettelli S, Dinelli G, 2012. Health-promoting phytochemicals of Italian common wheat varieties grown under low-input agricultural management. J. Sci. Food Agric. 92:2800-10.

Dupont FM, Hurkman WJ, Vensel WH, Tanaka C, Kothari KM, Chung OK, Altenbach SB, 2006. Protein accumulation and composition in wheat grains: effects of mineral nutrients and high temperature. Eur. J. Agron. 25:96-107.

Fardet A, 2010. New hypotheses for the health-protective mechanisms of whole-grain cereals: What is beyond fibre? Nutr. Res. Rev. 23:65134.

Fares C, Platani C, Baiano A, Menga V, 2010. Effect of processing and cooking on phenolic acid profile and antioxidant capacity of durum wheat pasta enriched with debranning fractions of wheat. Food Chem. 119:1023-9.

Fuentes-Zaragoza E, Riquelme-Navarrate MJ, Sanchez-Zapata E, Perez-Alvarez JA, 2010. Resistant starch as functional ingredient: a review. Food Res. Int. 43:931-42.

Flagella Z, 2006. Qualità nutrizionale e tecnologica del frumento duro. Ital. J. Agron. 1:203-39.

Gebruers K, Dornez, Bedo Z, Rakszegi M, Fras A, Boros D, Courtin CM, Delcour JA, 2010. Environment and Genotype Effects on the content of dietary fiber and its components in wheat in the HEALTHGRAIN diversity screen. J. Agric. Food Chem. 58:9353-61.

Gebruers K, Dornez E, Boros D, Fras A, Dynkowskaw, Bedo Z, Rakszegi M, Delcour JA, Courtin CM, 2008. Variation in the content of dietary fiber and components thereof in wheats in the HEALTH- 
GRAIN diversity screen. J. Agric. Food Chem. 56:9740-9.

Gil A, Ortega RM, Maldonado J, 2011. Wholegrain cereal and bread: a duet of the Mediterranean diet for the prevention of chronic diseases. Public Healt Nutr. 14:2316-22.

Giuliani MM, Giuzio L, De Caro A, Flagella Z, 2011. Relationships between nitrogen utilization and grain technological quality in durum wheat: II. Grain yield and quality. Agron. J. 103:1668-75.

Giunta F, Motzo R, Pruneddu G, 2007. Trends since 1900 in the yield potential of Italian-bred durum wheat cultivars. Eur. J. Agron. 27:12-24.

Hentschel V, Kranl K, Hollmann J, Lindhauer MG, Bohm V, Bitsch R, 2002. Spectrophotometric determination of yellow pigment content and evaluation of carotenoids by high-performance liquid chromatography in durum wheat grain. J. Agric. Food Chem. 50:6662-8.

Hung PV, Hatcher DW, 2011. Ultra-performance liquid chromatography (UPLC) quantification of carotenoids in durum wheat: influence of genotype and environment in relation to the colour of yellow alkaline noodles (YAN). Food Chem. 125:1510-6.

Jacobs DR Jr, Meyer KA, Kushi LH, Folsom AR, 1998. Whole grain intake may reduce risk of coronary heart disease death in postmenopausal women: the Iowa women's health study. Am. J. Clin. Nutr. 68:248-57.

Kieffer R, Schurer F, Kohler Pand Wieser H, 2007. Effect of hydrostatic pressure and temperature on the chemical and functional properties of wheat gluten: studies on gluten, gliadin and glutenin. J. Cereal. Sci. 45:285-92.

Labuschagne MT, Elago 0, Koen E, 2009. The influence of temperature extremes on some quality and starch characteristics in bread, biscuit and durum wheat. J. Cereal. Sci. 49:184-9.

Lammerts van Bueren, ET, Jones SS, Tamm L, Murphy KM, Myers JR, Leifert C, Messmer MM, 2011. The need to breed crop varieties suitable for organic farming using wheat, tomato and broccoli as examples: a review. NJAS-Wagen. J. Life. Sci. 58:193-205.

Marotti I, Bregola V, Aloisio I, Di Gioia D, Bosi S, Di Silvestro R, Quinn R, Dinelli G, 2012. Prebiotic effect of soluble fibres from modern and old durum-type wheat varieties on Lactobacillus and Bifidobacterium strains. J. Sci. Food Agric. 92:2133-40.

McLachlan GJ, 2004. Discriminant analysis and statistical pattern recognition. Wiley Interscience. John Wiley \& Sons Inc., Hoboken, NJ, USA.

Motzo R, Fois S, Giunta F, 2004. Relationship between grain yield and quality of durum wheats from different eras of breeding. Euphytica. 140:147-54.

Panfili G, Fratianni A, Irano M, 2004. Improved normal-phase high-performance liquid chromatography procedure for the determination of carotenoids in cereals. J. Agr. Food Chem. 52:6373-77.
Pecetti L, Annicchiarico P, 1998. Agronomic value and plant type of Italian durum wheat cultivars from different eras of breeding. Euphytica. 99:9-15.

Prosky L, Asp NG, Schwizer TF, De Vries JW, Furda I, 1988. Determination of insoluble, soluble and total dietary fiber in foods and food products: Interlaboratory study. J. Assoc. Off. Anal. Chem. $71: 1017-23$.

Quaranta F, Amoriello T, Aureli G, Belocchi A, D’Egidio MG, Fornara M, Melloni S, Desiderio E, 2010. Grain yield, quality and deoxynivalenol (DON) contamination of durum wheat (Triticum Durum Desf.): results of national networks in organic and conventional cropping systems. Ital. J. Agron. 4:353-66.

Ragaee S, Abdel-Aal EM, Noaman M, 2006. Antioxidant activity and nutrient composition of selected cereals for food use. Food Chem. 98:32-8.

Rodriguez-Delgado MA, Gonzalez-Hernandez G, Conde-Gonzalez JE, Perez-Trujillo JP, 2002. Principal component analysis of the polyphenol content in young red wines. Food Chem. 78:523-32.

Sajilata MG, Singhal RS, Kulkarni PK, 2006. Resistant starch - a review. Compr. Rev. Food Sci. F. 5:1-17.

Scarascia Mugnozza GT, 2005. The contribution of Italian wheat geneticists: from Nazareno Strampelli to Francesco D’Amato. Proc. Int. Congr. In the wake of the double helix: from the green devolution to the gene revolution, Bologna, Italy, pp 52-75.

Shewry PR, Piironen V, Lampi AM, Edelmann M, Kariluoto S, Nurmi T, Fernandez-Orozco R, Ravel C, Charmet G, Andersson AAM, Aman P, Boros D, Gebruers K, Dornez E, Courtin CM, Delcour JJA, Rakszegi M, Bedo Z, Ward JL, 2010. The HEALTHGRAIN wheat diversity screen: effects of genotype and environment on phytochemicals and dietary fiber components. J. Agric. Food Chem. 58:9291-8.

Singleton VL, Orthofer R, Lamuela-Raventos RM, 1999. Analysis of total phenols and other oxidation substrates and antioxidants by means of Folin-Ciocalteu reagent. Method. Enzymol. 299:152-78.

Stracke BA, Eitel J, Watzl B, Mader P, Rufer CE, 2009. Influence of the production method on phytochemical concentrations in whole wheat (Triticum aestivum L.): A comparative study. J. Agr. Food Chem. 57:10116-21.

Thompson LU, 1994. Antioxidant and hormone-mediated health benefits of whole grains. Crit. Rev. Food Sci. 34:473-97.

Topuz A, Ozdemir F, 2003. Influences of -irradiation and storage on the carotenoids of sun-dried and dehydrated paprika. J. Agric. Food Chem. 51:4972-7.

Vaccari FP, Ranieri R, Matese A, Miglietta F, 2007. Enhanced temperature during grain filling reduces protein concentration of durum wheat. Ital. J. Agron. 4:393-400. 